\title{
Historian monet puolet
}

Tekniikan historian vahvuus on sen monipuolisuudessa. Kiinnostus tekniikkaan yhdistää historian akateemiset ammattilaiset ja siitä kiinnostuneet harrastajat. Tekniikan historia toimii siltana menneisyyden ja tulevaisuuden tutkimuksen välillä ja herättää keskusteluja, joihin ihmistieteet voivat osallistua yhdessä luonnontieteiden kanssa.

Suomalaisen tekniikan historian foorumina Tekniikan Waiheita -lehdessä yhdistyvät nämä kaikki ulottuvuudet. Vertaisarvioidut tutkimukset muodostavat alan vankan perustan ja ovat välttämätön osa tekniikan historian uusiutumiselle ja elinvoimaisuudelle. Laajat katsaukset tekniikan historiaan liittyviin teemoihin, museotoimintaan ja uusiin julkaisuihin ovat kuitenkin yhtä tärkeä osa historiakulttuuria ja tieteellisiä keskusteluja.

Tämän syksyn kaksoisnumeron avaa Matti La Melan vertaisarvioitu tutkimus Suomen patenttijärjestelmän kehittymisestä. Kuten La Mela toteaa artikkelissaan, patentti on keksijän ja valtion välinen sopimus, jossa keksijä tuo keksintönsä julkisuuteen, mutta saa väliaikaisesti yksinoikeuden idean hyödyntämiseen. Menneisyyden patenttiarkistot tarjoavat historiantutkijalle avaramman portin teollisuuden kehitykseen. Historiankirjat muistavat hyvin vain harvat menestyksekkäät keksinnöt, mutta portin läpi yritti paljon laajempi joukko keksijöitä. La Melan artikkeli tarkastelee juuri tätä patenttihistorian marginaalia, hylättyjen patenttien joukkoa. Marginaalin kautta hahmottuu kuva keksijöistä, yrittäjistä ja unelmoijista, mutta erityisesti suomalaisen taloushallinnon kehittymisestä autonomian ajan loppupuolella.

Siinä, missä La Mela lähestyy tekniikan historiaa hallinnon arkistojen kautta, Maria Vanha-Similän laaja katsaus kodinkoneiden tulosta suomalaisiin koteihin tarkastelee tekniikan historiaa arkipäivän elämän kautta. Jokapäiväiset toiminnot ruuanlaitosta vaatehuoltoon muuttuivat ratkaisevasti ja nopeasti sotienjälkeisinä vuosikymmeninä, kun sähköliedet ja kylmäsäilytystekniikka mullistivat ruuan valmistuksen ja koneet ottivat päävastuun fyysisesti raskaimmista kotitöistä. Vanha-Similä tarkastelee muutosta erityisesti naisten näkökulmasta. Kodinkoneiden yleistyminen oli sekä seuraus että edellytys naisten siirtymiselle työelämään.

Parhaastakaan tutkimuksesta ei ole iloa, ellei tutkimustietoa onnistuta välittämään yliopistoista yhteiskuntaan. Museot ovat keskeisessä asemassa tieteen ja tutkimuksen kommunikoinnissa suurelle yleisölle. Uusi tekniikka tarjoaa uusia välineitä myös museoiden toimintaan. Aaro Saharin laaja katsaus Merikeskus Vellamon tänä kesänä avatun Kohtalona Ruotsinsalmi -näyttelyn taustoihin avaa kiinnostavalla tavalla esiin virtuaalitekniikkaan ja immersiivisiin museokokemuksiin liittyviä haasteita ja mahdollisuuksia.

Numeron kolmas katsaus suuntaa katseen tekniikan tutkimuksen tulevaisuuteen. Ylva Grufstedtin, Heidi Rautalahden ja Lysiane Lasaussen essee Helsingin yliopiston pelitutkimusverkostosta HeGRiCin perustamisesta luotaa pelitutkimuksen nykyistä asemaa pääkaupunkiseudulla ja monialaisen tutkimusverkoston tulevaisuutta. Tekniikka on erottamaton osa pelien ja pelaamisen historiaa, ja pelit ovat osa tekniikan historiaa. Metodit ja tutkimuskohteet voivat yhdistää menneisyyden, nykyisyyden ja tulevaisuuden peleistä kiinnostuneita tutkijoita monialaisessa verkostossa.

Kirja-arvostelujen tarkoituksena on paitsi esitellä ja arvostella uusia julkaisuja myös osallistua akateemisiin keskusteluihin. Numeron viimeistelee kolme kirja-arvostelua. Sampsa Kaatajan arvostelu Tarmo Lemolan teoksesta herättää keskustelua Suomen teknologia- ja 
innovaatiopolitiikan menneisyydestä ja nykytilasta. Mila Oivan arvostelu Ian Milliganin teoksesta kutsuu miettimään historiantutkimuksen käytäntöjä tulevaisuuden internet-arkistojen äärellä. Lopuksi Tuomas Pakarisen arvio haastavasta ja monipuolisesta "laatikkotutkimuksen" opaskirjasta esittelee uutta tieteen- ja teknologian tutkimusta.

Mukavia lukuhetkiä pimeneviin iltoihin!

\section{Saara Matala}

Päätoimittaja

To cite this article: Saara Matala, "Historian monet puolet" Tekniikan Waiheita 38, no. 3-4 (2020): 4-5. https://dx.doi.org/10.33355/tw.100574

To link to this article: https://dx.doi.org/10.33355/tw.100574 